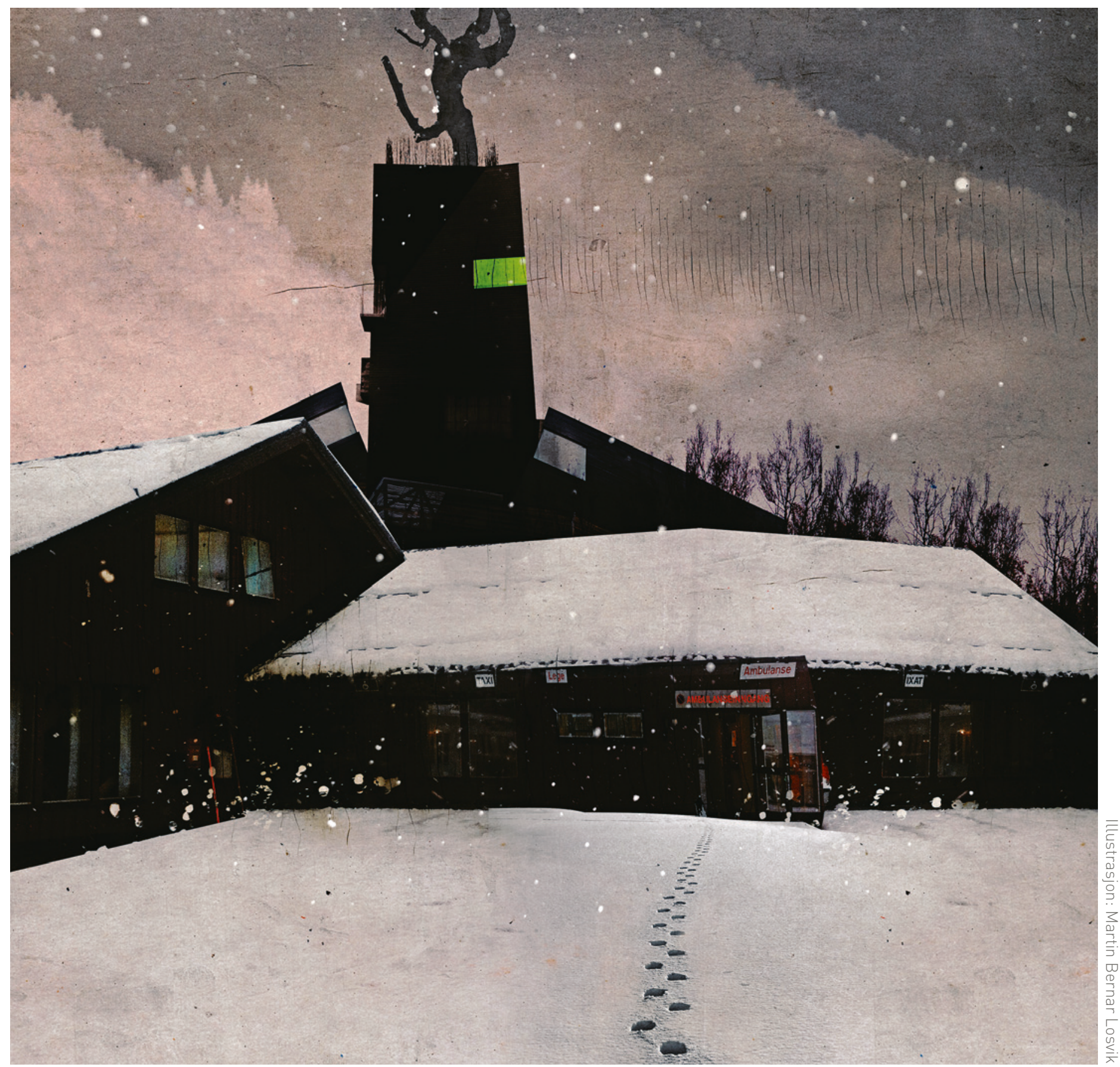

\title{
Oppeid legekontor og ambulanse
} I Hamarøy kommune i Salten i Nordland finner vi administrasjonssenteret Oppeid. Og på Oppeid finner man
legesenteret hvor også ambulansetjenesten, tilknyttet Nordlandssykehuset, har en ambulanse i døgnkonti-
nuerlig beredskap. Stasjonen har fire ansatte og utfører om lag 230 oppdrag i året. 